\title{
Sellar Region Neoplasm
}

National Cancer Institute

\section{Source}

National Cancer Institute. Sellar Region Neoplasm. NCI Thesaurus. Code C4944.

A benign or malignant neoplasm that occurs in the sellar region. Representative examples include craniopharyngioma and pituitary gland adenoma. 